\title{
THE USE OF CONVENTIONAL BANKS BY SHARIA ECONOMIC LAW STUDENTS: PRACTICE, FACTORS, AND LAWS
}

\author{
Dzaky Adam Thamrin ${ }^{1}$, Fauzul Hanif Noor Athief $^{2}$ \\ Universitas Muhammadiyah Surakarta \\ Dzakythamrin94@gmail.com¹, Fauzul.hanif@ums.ac.id²
}

\begin{abstract}
This study aims to reveal the factors and reasons behind the large number of Islamic Economic Law students using conventional banks which are then analysed with an Islamic law approach.

The method used in this study is descriptive quantitative and qualitative study. Data collection by survey and interview methods. The data analysis used descriptive and deductive analysis approach.

The results of this study found that most students use conventional banks, although half of them are aware of the concern of usury on interest. Nevertheless, in practice, only a small percentage of them separate bank interest from their savings. The majority of the reasons they use conventional banks are based on facilities, family and work. Under Islamic law, the use of conventional banks is haram, although there are cases where it is permissible under Islamic law.
\end{abstract}

Keywords: Conventional Banks, Students, Islamic Law.

\section{Introduction}

The emergence of bank 4,500 years ago in ancient Greece and Egypt, where there was already interest became an aspect that was closely related to the banking system even today. Interest in return for borrowing money has become an advantage for banks and has become a factor in the development of banking, because the interest proceeds from borrowing money are used to finance bank operations (Nurhadi, 2017). Banks that use this system are said to be conventional banks. The word conventional has a meaning that is based on general agreement (Layla, 2015), so that interest in the banking system has become a general agreement in managing banking. This has become a system that is tied between interest and the bank.

On the other hand, this agreement is contrary to Islamic teachings, that the use of interest is forbidden (haram) because of usury. One of them, this forbidden is reinforced by the fatwa issued by the Indonesian Ulema Council (MUI) in December 2003 regarding bank interest usury, that bank interest is forbidden (Hasbiyallah, 2008). The forbidden of bank interest has led to the existence of an alternative banking system, it is sharia bank.

The Sharia banking system was introduced in the modern era since 1963 in Egypt, with a bank called Mit Ghamr. Meanwhile, sharia banks in Indonesia were only realized after the 
issuance of Law No. 7 of 1992 and also with the establishment of Bank Muamalat in 1991 (Atabik, 2013). This bank implements a banking system without interest and elements that are forbidden in Islam, so that customers with Muslim backgrounds may avoid things that are forbidden in Islam.

Although sharia banks have great potential in Indonesia since they have the largest Muslim population in the world. The development of sharia banks has not been able to replace the role of conventional banks. This reason is proven statistically by observing at the assets between conventional banks and sharia banks. According to data from the Financial Services Authority (2020) as of November 2019, the total assets of conventional banks were 8,075 trillion rupiah and the total assets of sharia banks was 335 trillion rupiah.

One of the users of conventional banks is a student majoring in sharia economic law at the Muhammadiyah University of Surakarta (UMS). In fact, they are students majoring in Sharia Economic Law who should be at the forefront to advance the sharia economy. Ideally, these students prefer sharia banks to conventional banks. From this it can be seen that there is no continuity between the lessons that have been studied in theory and in reality.

A similar study was conducted by Jasa in 2014 with the same study site which focused on factors that affect saving at conventional banks. The results of his study found that the reasons for not using sharia banks because of the lack of strategic sharia bank facilities, incomplete services and facilities, large administrative costs, and lack of trust (Jasa, 2014).

This article aims to study the development of students in those study program after six years with the aspects of quantity, concerns, usage practices, and Islamic law in viewing the usage practices carried out. I hope that the results of this study may be used as material for evaluation, input and suggestions for the world of education and the sharia banking industry.

\section{Review of Related Literature}

The discussion on the factors of using conventional banks by customers with Muslim backgrounds has been studied by several previous researchers. One of them is Jasa (2014) which found that customers do not save in sharia banks due to factors that are less strategic in banking facilities, unsatisfactory services, Automated Teller Machines (ATMs) that do not reach some areas, sharia bank has larger administrative costs, and lack of trust. This is different from conventional banks whose access has reached broadly to the needs of the community.

Pandega (2018) states in his study that the facility factor affects customer interest in conventional banks in terms of employee credibility and ease of disbursement and withdrawal of funds. Likewise, Febriasti (2014) in her study states that service factors have a significant influence in choosing sharia banks. Umairoh (2017) in her study found that Islamic bank services are a factor that causes customers to be reluctant to use Islamic banks. Susanti (2020) 
and Sumara (2017) in their study also state that family factors have a significant and strong influence on customer decisions in choosing a bank. Setyawan (2014) in his study at the bank Danamon states that the influence of bank selection lies significantly on guarantees and trust. Patriana (2018) corroborates by mentioning that Muslim consumers choose conventional banks because of a higher reputation for guarantees than sharia banks for customers.

In discussing the legal use of conventional banks, Wahyudi (2014) in his research comparing the views of Yusuf Qardhawi and Abdul Aziz Bin Baz regarding conventional banks regarding systems, work laws, and salaries) in which Yusuf Qardhawi stated that not all transactions in conventional banks contain usury, but the forbidden lies only in interest while Abdul Aziz Bin Baz stated that all transactions in conventional banks contain usury.

\section{Study Method}

This study is a quantitative and qualitative study with a descriptive approach conducted at the Muhammadiyah University of Surakarta, sharia economic law study program. Data collection using survey and interview methods. The sample data are 112 students.

\section{Results and Discussion}

\section{Distribution \& Demographics of Respondents}

The selected respondents have different backgrounds. Therefore, the demographic distribution is divided based on four things, generation, gender, income, and source of income.

Table 1

\section{Distribution \& Demographics of Respondents}

\begin{tabular}{|c|c|c|c|}
\hline & & Number & Percentage \\
\hline \multirow{3}{*}{ Generation } & Semester 8 & 52 & $46.4 \%$ \\
\cline { 2 - 4 } & Semester 6 & 60 & $53.6 \%$ \\
\hline \multirow{3}{*}{ Gender } & Male & 55 & $49.1 \%$ \\
\cline { 2 - 4 } & Female & 57 & $50.9 \%$ \\
\hline \multirow{3}{*}{ Monthly Income (in Rupiah) } & $<1,000,000$ & 59 & $52.7 \%$ \\
\cline { 2 - 4 } & $1,000,000-2,000,000$ & 49 & $43.8 \%$ \\
\cline { 2 - 4 } & $>2,000,000$ & 4 & $3.6 \%$ \\
\hline \multirow{3}{*}{ Source of Incomes } & Family & 84 & $75 \%$ \\
\cline { 2 - 4 } & Occupation & 16 & $14.3 \%$ \\
\cline { 2 - 4 } & Family \& Occupation & 10 & $8.9 \%$ \\
\cline { 2 - 4 } & Others & 2 & $1.8 \%$ \\
\hline
\end{tabular}

Source: Processed study data 


\section{Number of Conventional Bank Users}

The table below shows that more than three quarters of respondents use conventional banks. Meanwhile, state-owned conventional banks have a large number of users compared to private-owned conventional banks.

Table 2

Comparison of Conventional \& Sharia Bank Users

\begin{tabular}{|c|c|c|c|c|}
\hline & & $\mathrm{Nu}$ & & Percentage \\
\hline \multirow{3}{*}{$\begin{array}{c}\text { Conventional } \\
\text { Bank Users }\end{array}$} & State-Owned & 76 & \multirow{3}{*}{87} & \multirow{3}{*}{$77.7 \%$} \\
\hline & $\begin{array}{l}\text { Private- } \\
\text { Owned }\end{array}$ & 5 & & \\
\hline & $\begin{array}{c}\text { State- Owned } \\
\text { and Private- } \\
\text { Owned }\end{array}$ & 6 & & \\
\hline \multicolumn{2}{|c|}{ Sharia Bank Users } & \multicolumn{2}{|c|}{25} & $22.3 \%$ \\
\hline
\end{tabular}

\section{Source: Processed study data}

\section{Factors for Using Conventional Banks}

Factors in the use of banks are divided into four scopes, namely the use of banks by respondents based on function (Ahman, 2007), emergency conditions in using conventional banks, concerns about usury in bank interest, and actions in separating bank interest from savings.

\section{Table 3}

\section{Conventional Bank Usage Practices}

\begin{tabular}{|c|c|c|c|}
\hline & & Number & Percentage \\
\hline \multirow{2}{*}{$\begin{array}{l}\text { Functions of Using Conventional } \\
\text { Banks }\end{array}$} & Savings & 87 & $100 \%$ \\
\hline & Loans & 0 & $0 \%$ \\
\hline \multirow{5}{*}{$\begin{array}{l}\text { Emergencies Conditions in Using } \\
\text { Conventional Banks }\end{array}$} & Strongly agree & 13 & $14.9 \%$ \\
\hline & Agree & 23 & $26.4 \%$ \\
\hline & Uncertain & 31 & $35.6 \%$ \\
\hline & Disagree & 12 & $13.8 \%$ \\
\hline & Strongly disagree & 8 & $9.2 \%$ \\
\hline \multirow{5}{*}{$\begin{array}{l}\text { Respondents' level of concern about } \\
\text { the existence of usury in bank } \\
\text { interest }\end{array}$} & $100 \%$ Concern & 48 & $55.2 \%$ \\
\hline & $75 \%$ Concern & 18 & $20.7 \%$ \\
\hline & $50 \%$ Concern & 15 & $17.2 \%$ \\
\hline & $25 \%$ Concern & 2 & $2.3 \%$ \\
\hline & $0 \%$ Concern & 4 & $4.6 \%$ \\
\hline \multirow{2}{*}{$\begin{array}{l}\text { Separation of bank interest from } \\
\text { savings }\end{array}$} & Separate & 27 & $31 \%$ \\
\hline & Not separate & 60 & $69 \%$ \\
\hline
\end{tabular}

\section{Source: Processed study data}


The data above shows that the reason for using conventional banks is only for saving and payment traffic. The majority of respondents chose to be unsure whether to use conventional banks due to an emergency situation due to the lack of sharia banks. While the results regarding the respondents' concerns about interest are quite high, it is $55.2 \%$. Surprisingly, although the majority of respondents have high concerns, more than two thirds of respondents do not separate bank interest from savings. Respondents who separated bank interest from their savings were carried out in various ways, including: 1) Checking the balance in the savings account at a certain time, if the balance has interest with an amount that can be cashed out, it will be separated 2) Calculate the amount of interest in savings at the time of closing the bank account. The amount of money from interest will be issued after the account at the bank used by the respondent is closed. On the other hand, some reasons of respondents who do not separate bank interest from savings are: 1) The interest given by conventional banks does not have a significant advantage and the amount is very small when compared to the administrative costs incurred by customers 2) It is unthinkable that there will be interest in savings.

\section{Factors Causing the Use of Conventional Banks}

There are several factors that influence the use of conventional banks by students, including six factors, they are facilities, services, guarantees \& trust, administrative costs, bank products, and family. In addition to such six factors, there are questions about other factors exclude it. Questions regarding this factor are not only addressed to conventional bank users, but also Islamic bank users to see the possibility of users switching to conventional banks if there are reasons for the six factors mentioned.

\section{Table 4}

Factors Causing the Use of Conventional Banks

\begin{tabular}{|l|l|c|c|c|c|c|}
\hline \multicolumn{2}{|c|}{} & $\begin{array}{c}\text { Strongly } \\
\text { Agree }\end{array}$ & $\begin{array}{c}\text { Agre } \\
\text { e }\end{array}$ & $\begin{array}{c}\text { Uncerta } \\
\text { in }\end{array}$ & $\begin{array}{c}\text { Disagre } \\
\text { e }\end{array}$ & $\begin{array}{c}\text { Strong1 } \\
\text { y } \\
\text { Disagre } \\
\text { e }\end{array}$ \\
\hline \multirow{2}{*}{$\begin{array}{l}\text { Facility } \\
\text { Factor }\end{array}$} & Conventional Bank Users & 31 & 24 & 24 & 5 & 3 \\
\cline { 2 - 7 } & Sharia Bank Users & 1 & 0 & 7 & 5 & 12 \\
\hline $\begin{array}{l}\text { Service } \\
\text { Factor }\end{array}$ & Conventional Bank Users & 11 & 19 & 36 & 16 & 5 \\
\cline { 2 - 7 } $\begin{array}{l}\text { Guarantee } \\
\text { and Trust } \\
\text { Factor }\end{array}$ & Sharia Bank Users & 1 & 1 & 8 & 4 & 11 \\
\cline { 2 - 7 } & Conventional Bank Users & 4 & 25 & 33 & 19 & 6 \\
\hline
\end{tabular}




\begin{tabular}{|l|l|c|c|c|c|c|}
\hline $\begin{array}{l}\text { Administrat } \\
\text { ion Cost } \\
\text { Factor }\end{array}$ & Sharia Bank Users & 1 & 1 & 7 & 5 & 11 \\
\hline $\begin{array}{l}\text { Bank } \\
\text { Products } \\
\text { Factor }\end{array}$ & Conventional Bank Users & 4 & 21 & 29 & 21 & 12 \\
\cline { 2 - 7 } Family & Sharia Bank Users & 1 & 3 & 4 & 4 & 13 \\
Factor & Conventional Bank Users & 12 & 28 & 26 & 8 & 13 \\
\cline { 2 - 7 } & Sharia Bank Users & 1 & 2 & 8 & 4 & 10 \\
\hline
\end{tabular}

\section{Source: Processed study data}

From table 4 shows that the facility factor has a high value. This is due to their need for the existence of banks in rural areas that may only be reached by conventional banks such as BRI (Bank Rakyat Indonesia). In addition to the facility factor, the family factor also has a high value. Family factor is due to equating savings with parents who use conventional banks to save on transfer costs. This is because it equates the bank used by parents who use conventional banks so that it saves on transfer fees.

On the part of sharia bank users, the majority strongly disagree with the six factors mentioned. This means that the majority of Islamic bank users will not switch to conventional banks if they have the causes of these six factors. Another factor found in this study is the work factor caused by the demands of the policy from the office.

\section{Islamic Law Review on the Use of Conventional Banks}

In the review of Islamic law referred to by the fatwa of the Tarjih Muhammadiyah assembly, the opinion of Yusuf Qardhawi (Egypt Mujtahid), and Muhammad Syafi'i Antonio (Islamic economist) on the use of banks based on ownership, separation of savings from bank interest, and the use of banks with an emergency element.

\section{Use of Banks Based on Ownership}

In this explanation, ownership in conventional banks has legal differences that are fatwaed in the Muhammadiyah Tarjih Council. As is the position of the tarjih decision as one of the fatwas, where the fatwa in Islamic law has an important position as a result of collective ijtihad that is ikhtirahiyah (optional) (Riadi, 2010).

The fatwa states that there are legal differences that are seen in Muhammadiyah's tarjih decision against government-owned conventional banks and privately-owned conventional banks. These two conventional banks have the same system, where bank interest is one of the systems in the flow of funds to the two banks.

The decision of Tarjih Muhammadiyah in Sidoarjo gave forbidden laws to privateowned conventional banks, while the use of state-owned conventional banks was decided to 
include musytabihat cases. This is because privately-owned conventional banks have interest that is used for personal interests, while the interest of government-owned conventional banks is used for the common good (Central Leadership of Muhammadiyah, 2014).

However, this musytabihat case has been broken and the fatwa renewed to be forbidden by the Tarjih Council and Tajdid of Muhammadiyah Central Executive in 2006 in Yogyakarta (Central Leadership of Muhammadiyah, 2018). In addition, the impact that has occurred in third world countries is the debt crisis. Besides that, there are also other fatwas that form the basis for the new Muhammadiyah fatwa on the unlawful interest case, including: 1) Decision of the Second Congress of the Islamic Research Institute (Majma' al-Buhuf al-Islamiyyah) AlAzhar, Cairo, Muharam 1385 H / May 1965. 2) Decision of the Second Islamic Bank Congress, Kuwait, 1403 H / 1983. 3) Decision of the Second Congress of the Organization of Islamic Jurisprudence Organization of the Islamic Conference (OIC), Jeddah, 10-16 Rabiul Akhir 1406 / 22-28 December 1985. 4) Decision of Session IX of the Council of Islamic Jurisprudence, Rabitah Alam Islami (Muslim World League) Mecca, 19 Rajab 1406 H / 1986. 5) Fatwa of the Al-Azhar Fatwa Committee dated 28 February 1988. 6) Fatwa of Dar Al-Ifta' Egypt dated 2002-1989 which was signed by the Mufti of the State of Egypt which stated, "Every loan (credit) with a predetermined interest is forbidden."

\section{Actions in Separating Savings with Bank Interest}

Yusuf Qardhawi has the opinion that not everything in conventional banks is forbidden, except for bank interest. Bank interest is the basic reason for the existence of an element of forbidden in using conventional banks, so separation actions shall be taken to avoid mixing truth and falsehood. As in the letter Al-Baqarah verse 42 which reads:

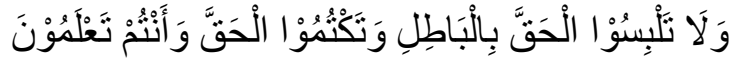

"Do not confound the truth by mixing it with falsehood, and do not conceal the truth while you know"

Muhammadiyah issued a fatwa on the use of state-owned conventional banks as forbidden case. Therefore, to avoid falsehood in bank interest from using conventional banks, the separation of interest from savings is carried out in both small and large amounts.

\section{Use of Conventional Banks with Emergency Elements}

The use of conventional banks in an emergency conditions is still valid due to the facility factor. This factor means that respondents use conventional banks because the location of bank facilities, both ATMs, branch offices, and others is affordable. In some cases, respondents use conventional banks because only conventional banks are available in their home areas to transfer money from the respondent's parents for the necessities of life in the respondent's college. 
When referring to the word emergency, which is described by an Islamic economist Muhammad Syafi'i Antonio, it is emphasized that an emergency is emphasized if someone does not do it, then the impact will lead to death or destruction (Antonio, 2001). In this case, it is permissible to use conventional banks because of an emergency element. Since if the respondent's parents do not use conventional banks to transfer money for the respondent's living needs and college needs, it will bring disaster to the respondent because the needs of life are not fulfilled due to the lack of money.

\section{Conclusion}

The conclusion that we can draw from the results of this study is the factor of using conventional banks for saving and payment traffic. There are $55.2 \%$ of respondents have very high concerns about the forbidden of bank interest, but even so, most of them do not separate bank interest from savings.

Factors of facilities, family and work are the causes of most respondents using conventional banks. Respondents rated uncertain on the factors of service, guarantee and trust, administrative costs, and bank products. On the other hand, the majority of respondents who use sharia banks will not use conventional banks if these factors occur.

Regarding the use of conventional banks in terms of Islamic law, private-owned and government-owned banks are forbidden due to bank interest, so the separation of savings and interest shall be done to maintain religion by avoiding falsehood in bank interest. Regarding emergency conditions to use conventional banks, it is permissible and applicable if only conventional banks are available in their area of origin to transfer money from the respondent's parents for the respondent's living and educational needs.

\section{BIBLIOGRAPHY}

Ahman, E. (2007). Ekonomi Dan Akuntansi. Grafindo.

Antonio, M. S. (2001). Bank Syariah Dari Teori Ke Praktik. Gema Insani.

Atabik, A. (2013). Analisis Historis Perkembangan Bank Syariah. Iqtishadia, 6(2).

Febriasti, R. H. (2014). Faktor-Faktor Yang Menyebabkan Keputusan Mabasiswa Menabung Di Bank Syariah Mandiri Yogyakarta [Thesis]. Sunan Kalijaga State Islamic University of Yogyakarta.

Hasbiyallah. (2008). Fikih. Grafindo.

Jasa, F. Z. T. (2014). Faktor-Faktor Yang Menyebabkan Mahasiswa Fakultas Agama Islam Program Studi Muamalat (Syariah) Universitas Muhammadiyah Surakarta Tidak. Menabung Di Bank Syariah [Thesis]. Muhammadiyah University of Surakarta.

Layla. (2015). Kamus Lengkap Bahasa Indonesia. Palanta.

Nurhadi. (2017). Bunga Bank Antara Halal Dan Haram. Nur El-Islam, 4(2). 
Otoritas Jasa Keuangan. (2020). Statistik Perbankan Indonesia Vol. 17 No. 12. OJK.

Pandega, G. S. (2018). Analisis Faktor Dalam Pemilihan Bank Konvensional Sebagai Tempat Menabung Pada Mahasiswa Unnes [Thesis]. Semarang State University.

Patriana, E. (2018). Analisis Faktor Penentu Keputusan Konsumen Muslim Dalam Memilih Jasa Perbankan: Bank Syariah Vs Bank Konvensional. Al-Masraf, 3(1).

Pimpinan Pusat Muhammadiyah. (2014). Himpunan Putusan Tariih Mubammadiyah. Suara Muhammadiyah.

Pimpinan Pusat Muhammadiyah. (2018). Himpunan Putusan Tarjih Muhammadiyah Jilid 3. Suara Muhammadiyah.

Riadi, M. E. (2010). Kedudukan Fatwa Ditinjau Dari Hukum Islam Dan Hukum Positif (Analisis Yuridis Normatif). Ulumuddin, 7(1).

Setyawan, Y. N. (2014). Analisa Pengaruh Kepercayaan, Jaminan Rasa Aman, Dan Aksesibilitas Terhadap Minat Menabung Nasabah Bank Danamon Di Surabaya. Petra, 2(1).

Sumara, A. Y. (2017). Analisis Faktor-Faktor Yang Mempengarubi Keputusan Nasabah Muslim Untuk Memilib Bank. Konvensional (Studi Pada Mahasiswa Fakultas Ekonomi Dan Bisnis Islam UIN Kalijaga) [Thesis]. Sunan Kalijaga State Islamic University of Yogyakarta..

Susanti, I. (2020). Pengaruh Faktor Keluarga, Religiusitas, Dan Kualitas Produk Terhadap Keputusan Nasabah Memilih Bank Konvensional. Malia, 11(2).

Umairoh, R. (2017). Preferensi Nasabah Muslim Tidak. Menggunakan Bank Syariah (Studi Kasus Pada Mahasiswa UIN Sunan Kalijaga, UMY, Dan UII) [Thesis]. Sunan Kalijaga State Islamic University of Yogyakarta..

Umar, H. (2003). Metode Riset Bisnis. Gramedia.

Wahyudi, M. A. (2014). Pemikiran Yusuf Qardhawi Dan Abdul Aziz Bin Baz. Tentang Bank. Konvensional (Studi Komparatif Tentang Sistem, Hukum Bekerja, Dan Gaji) [Thesis]. Sunan Ampel State Islamic University of Surabaya. 